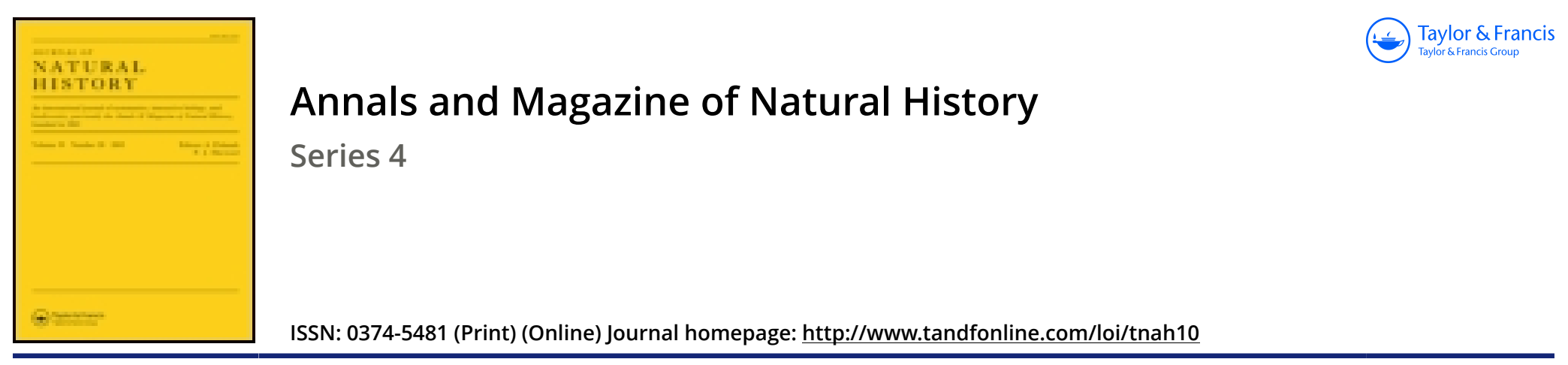

\title{
XXXI.-Descriptions of some new species of reptiles from Madagascar
}

\section{Dr. Albert Günther F.R.S.}

To cite this article: Dr. Albert Günther F.R.S. (1877) XXXI.—Descriptions of some new species of reptiles from Madagascar , Annals and Magazine of Natural History, 19:112, 313-317, DOI: 10.1080/00222937708682150

To link to this article: http://dx.doi.org/10.1080/00222937708682150

$$
\text { 册 Published online: } 13 \text { Oct } 2009 .
$$

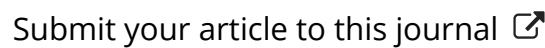

Џ Article views: 4 
falo River which appears to be undescribed. Although the length of the largest specimen does not exceed 4 inches, dissection shows that individuals of that size are fully adult.

\section{Barbus Trevelyani.}

\section{10 . A. 8 . L. lat. 34 . L. transv. $6 / 3 \frac{1}{2}$.}

Barbels two only, of small size. The osseous dorsal ray is very slender, stiff, with very minute, almost imperceptible posterior serrature. Three longitudinal series of scales between the lateral line and ventral fin. Body oblong, its depth being two sevenths or one fourth of the total length (without caudal), the length of the head one fourth. The depth of the head is less than its length without snout. The aiameter of the eye is one fourth of the length of the head, and rather less than that of the snout, or than the width of the interorbital space (which is somewhat convex). Snout rather obtuse; mouth inferior, small. Dorsal fin of less height than the body, commencing a little behind the origin of the ventral, its first ray being equidistant between the end of the snout and the root of the caudal. Anal small; caudal rather decply forked. The pectoral does not extend to the ventral. $\Lambda$ narrow dark band runs along the middle of the side, and terminates in a round blackish spot at the root of the caudal.

XXXI.-Descriptions of some new Species of Reptiles from Madagascar. By Dr. AlberT GüNTher, F.R.S., Keeper of the Zoological Department, British Museum.

[Plate XVI.]

THe novelties described in this paper were contained in some small collections recently received by the British Museum from Madagascar. As regards the localities, MI. Grandidier has kindly informed me that Anzahamaru is the name of a small villiage, most probably close to Mahanoro, and that it is a name very common throughout Madagascar, meaning a locality where theie are many country-houses. Mahanoro is a short distance south of Tamatave.

Acontias holomelas. (Pl. XVI. fig. A.)

Middle of the body surrounded by 31 series of scales; 140 scales in the series running from the chin to the vent. Length 
Ann.\& Mag. Nat.Hist. S.4. Vol.19.Pl.XVI.

A.
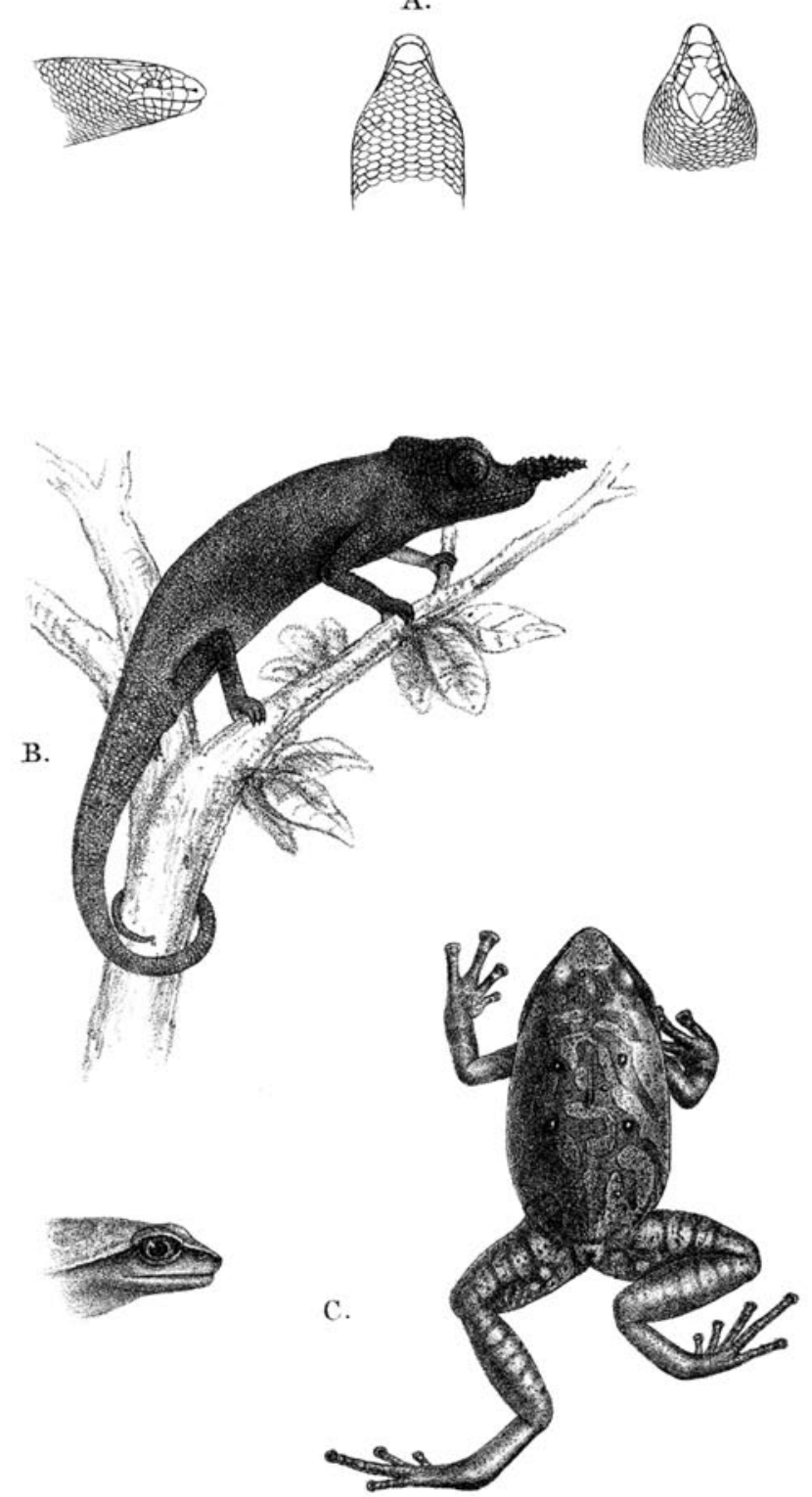

RMintern del.et lith.

Mintern Bros . imp.

A. ACONTIAS HOLOMELAS. B. CHAMALEON GALLUS. C. CALLULA NOTOSTICTA. 
of the rostral shield half that of the snout, the part below the nasal slit being shorter than that above it. The first three upper labials nearly as high as long, the third being below the eye. Vertical longer than broad. Four præanal scutes, the two middle ones being the largest. Entirely black.

The length of the body of our largest specimen, without the tail, which is more or less injured, is nearly 6 inches.

From Anzahamaru.

\section{Gongylus melanurus.}

Rostral shield with an upper undulated margin; supranasals in contact with each other; frontal broad, single, with a straight posterior margin; vertical large, bell-shaped, narrower in front than behind, with an excision in the middle of its hind margin, the small central occipital fitting into the excision; one pair of occipitals.

Nostrils situated entirely within the rostral shield; postnasal smaller than loreal. Six upper labials, the fourth being the largest and situated below the eye.

Front lower labial narrow, followed by a single mental, which is broader than long. Six lower labials.

Eyelid scaly. Ear-opening small, round.

Body surrounded by 26 longitudinal series of scales. There are 82 transverse series of scales between the mental and the vent, which high number sufficiently indicates the slenderness of the body.

Four præanal scales, the two central ones being the largest.

Fore limbs extremely small, with a longitudinal groove on the side of the body, into which they can be received when the animal is burrowing underground. When laid forwards they scarcely reach the ear-opening. Toes very short, third and fourth equal in length. The hind $\operatorname{limb}$ and toes very short, the second and fifth toes equal in length, the fourth one fourth longer than the third.

Upper parts brown, sometimes black, sometimes brown mottled with darker. Abdomen whitish. Tail generally entirely blackish.

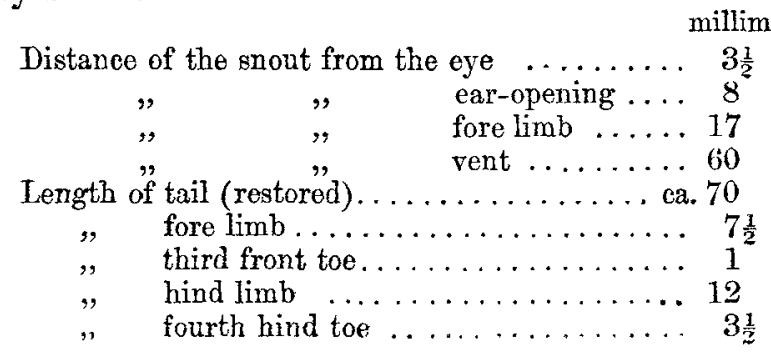


Three specimens from Anzahamaru; one specimen from Mahanoro.

\section{Gongylus melanopleura.}

Rostral shield low, narrow, with an upper straight margin ; supranasals in contact with each other; frontal nearly as long as broad, subtriangular, with an undulated posterior margin; vertical large, bell-shaped, much narrower in front than behind, with an excision in the middle of its hind margin, the central occipital fitting into the excision. One pair of occipitals.

Nostrils situated entirely within the rostral shield; postnasal smaller than loreal. Six upper labials, the fourth being the longest and situated below the eye.

Front lower labial small and narrow, followed by a single mental of a pentagonal shape. Six lower labials.

Eyelid with a transparent disk. Ear-opening small, round.

Body surrounded by 25 longitudinal series of scales; there are 54 transverse series of scales between the mental and the vent. Four præanal scales, the two central ones being the largest.

Fore limbs extremely small, with a postaxillary groove not well developed. When laid forward they do not reach the ear-opening. Toes very short, third and fourth equal in length. The hind limb short with very short toes, the second and fifth being equal in length, and the fourth one fourth longer than the third.

Upper parts brown, sprinkled with black. Sides towards the back black, this colour forming a band ill-defined below and margined with white above.

Lower part of sides dotted with black. Abdomen whitish.

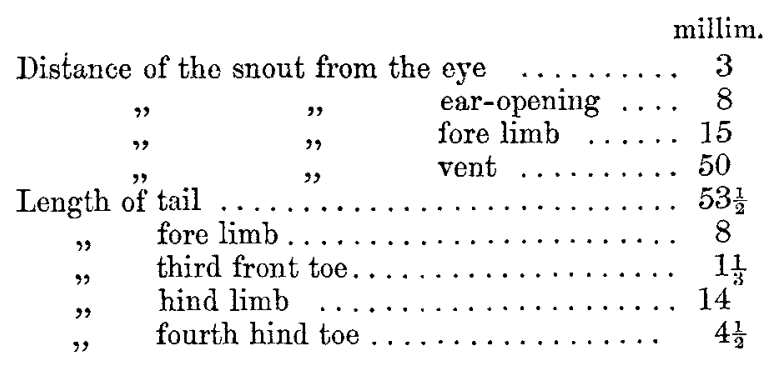

One specimen from Anzahamaru.

\section{Chamceleon gallus. (Pl. XVI. fig. B.)}

Allied to Chamoeleon nasutus. Snout with a long, pointed, flexible appendage (in the male), which is covered with large 
soft tubercles. Head compressed, without median crest. No spines whatever along the median line of the back; no crest along the belly. Body uniformly granular, without larger scales. Head and occiput covered with smooth, small, polygonal shields. Toes very short, with very small claws.

Coloration without particular markings.

Of this small species we possess only one example, 93 millims. long, the nasal appendage being 7 , and the tail 45 millims.

Mahanoro.

\section{Rana inguinalis.}

Head rather longer than broad, with the smout pointed, and with the loreal region high and subvertical. Canthus rostralis angular; nostril immediately below it, nearer to the end of the snout than to the eye. Tympanum two thirds the size of the eye. Vomerine teeth inconspicuous, between the choanæ, which are rather small, round. Skin nearly smooth, without folds. Limbs and toes slender. First and fourth toes longer than the second; third longest. Toes broadly webbed, the web reaching the penultimate phalanx of the fourth toe; the third and fifth toes equal in length. Metatarsus with one small tubercle. Upper parts brownish grey, with small subsymmetrical brown spots; a subtriangular brown spot between the eyes. A blackish band below the canthus rostralis and the supratympanic fold. A deep-black spot in the inguinal region. Limbs with brownish cross bars. Lower parts whitish.

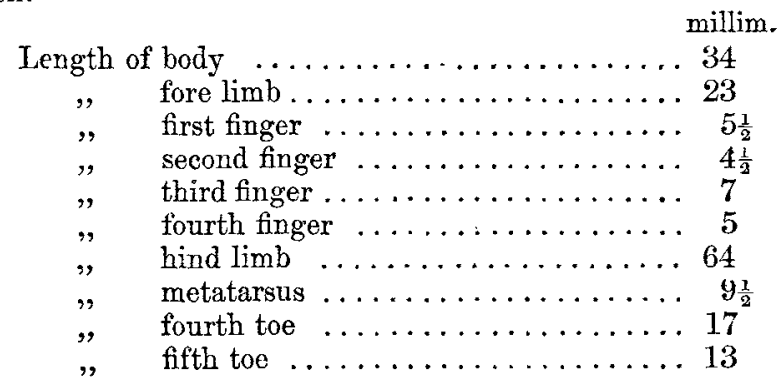

One specimen from Anzahamaru.

\section{Callula notosticta. (PI. XVI. fig. C.)}

Snout short, rather pointed, with distinct canthus rostralis. Limbs of moderate length. Disks well developed, especially on the three outer fingers and fourth toe. Inner finger shortest; third toe longer than fifth. Metatarsus without 
tubercle; toes not webbed. A fold of the skin runs from the superciliary margin along the middle of the side towards the inguinal region, separating the pink coloration of the back from the dull yellowish of the lower parts. Upper parts subsymmetrically marbled with light brown; two or three pairs of whitish dots edged with black on the back, the most constant being that corresponding to the extremities of the sacral apophyses. The front pair are minute, between the eyes; others, very minute, are scattered in the coccygeal region. Sides of the head blackish. Young specimens nearly uniform pink above.

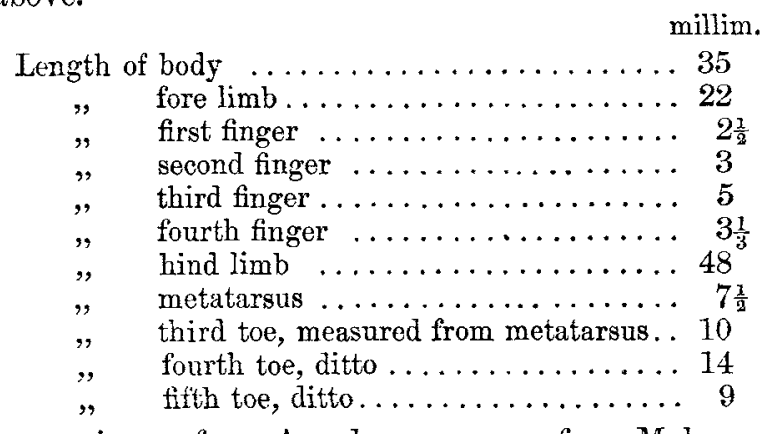

Two specimens from Anzahamaru; one from Mahanoro.

M. Grandidier has most kindly allowed me to examine the specimens of Callula (and other reptiles) recently named by him; he himself has expressed his doubts as to the propriety of referring these frogs to the Indian genus Callula, in which I fully agree with him. They are undoubtedly adult specimens of his highly interesting genus Dyscophus (a Discoglossoid). Singularly enough the discovery of Callula notosticta reestablishes the fact that Callula, or at least a form most closely allied to it, really occurs in Madagascar.

XXXII-New and peculiar Mollusca of the Eulimidæ and other Families of Gastropoda, as well as of the Pteropoda, procured in the 'Valorous' Expedition. By J. GWYN JEFFREYS, LL.D., F.R.S.

\section{Eulimidæ.}

Eulima stenostoma, Jeffr.

Eulima stenostoma, Jeffr. in Ann. \& Mag. Nat. Hist. 3rd ser. ii. p. 128, pl. v. f. 7 .

Station 6, 410 fms. Shetland, 75-90 fms. (J.G.J.). Nor- 